は $30^{\circ} \mathrm{C}$ 程度が適当で、この時の塩化アルミニウムの反応液への 溶解度は $0.2 \%$ である。つぎに，反応液に溶解していない触媒を 立とする液相を分離した後， $60^{\circ} \mathrm{C}$ に温度を上げて熟成する方法 が適している。熟成時間は長いはどよいが，30〜60 分で十分て ある。以上の条件で反応させると，塩化シクロへキシルの約 $85 \%$ がフェニルシクロヘキサンとなり，他はジシクロヘキシルベンゼ ンを主体とする高次縮合物である。

（3）反応生成物からフェニルシクロへキサンを蒸留分離した 後の残贸は, 縮合反応の熟成工程に添加し，さらにジスプロポー ションさせて最す効果的比フルシクロヘキサンにもどされ る。この熟成工程ではシクロヘキシル基が，塩化シクロヘキシル から供給されたものでも，高次縮合物中のるのでる全く等洒值を 示す。そこで高次樎合物を 1 回循環させただけでも，塩化シク口 ヘキシル基準の取率は $97.8 \%$ に達する。

（4）塩化シクロヘキシルとベンゼンのフリーデル・クラフッ 反応液は，盐化アルミニウムを主体とする蚛媒錯体相と，わずか の塩化アルミニウムを溶解した有機液相とから成立っている。
触媒錯体相では，塩化アルミニウムが塩化シクロヘキシルを引 きつけるために，ベンゼンと塩化シクロヘキシルの比率が小さく なって特り，この相に掓る反応では，比較的高次の縮合物が生 成するものと考えられる。生成物は有機液相との間で交换されて 行くのであるち。

一方，ベンゼン相は，少量の塩化アルミニウムを溶解し，しか す水分などは触媒錯体相に吸収されて除去されているので，理想 的なフリーデル・クラフッ樎合系を形成していると考えられる。 そこで，このような有機液相では，新たに加えられる塩化シク口 ヘキシルおよびポリシクロヘキシルベンゼン，さらに触媒錯体相 からのポリシクロヘキシルベンゼンの大部分を，フェニルシクロ へキサンに転化するのであろう。

（昭和 36 年 4 月，日化第 14 年会㗕演）

御指尊をいただいた東京工業大学岩會義男数授，ならびに当社 専務取締役 高瀬理三郎氏に感謝いたします。また実挽に協力さ れた当所 新沼輝久氏に感謝いたします。

\title{
フェニルシクロヘキサンの酸 化
}

(昭 和 36 年 5 月 19 日受理)

中村 寿太郎・表 雄 一*

\begin{abstract}
フェニルシクロヘキサンを液相で，常王あるいは加圧の下に酸素または空気で酸化し；フェニルシクロヘキサンヒドロ ペルオキシドを得る方法について研究した。フェニルシクロヘキサンは，クメンに比較して酸化を受け難く，またそのと ドロペルオキシドも不安定であるが，水酸化カルシウムあるいは炭酸水素ナトリウム等の弱フルカリ性物䝷の存在の下で

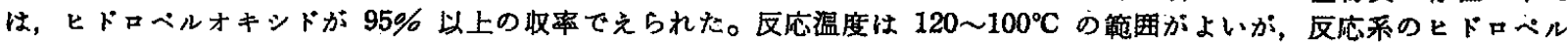
オキシドの濃度の低いうちは，温度は幾分高い方がよい。反分開始剂として，ヒドロペルオキシド自身が役立つ。フェニ ルシクロへキサン液相と酸素を含むガスとの接触面を大きくする必要があり，反沈系のかきまぜは特に重要である。反応

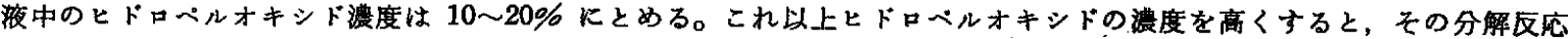
が激しくなり，高い收率を得ることが因難であった。
\end{abstract}

\section{1 緒 訾}

ベンゼン核に対して $\alpha$ 位置にある第 3 級炭素原子は酸化され やすく，酸素と結合してヒドロペルオキシドを生成する。クメン はその代表例であるが, フェニルシクロヘキサンも同じような条 件で酸化されて 1-フェニルシクロヘキサン-1-ヒドロベルオキシ ドを生成する。その生成条件については，すで若干の報告があ るが，ヒドロペルオキシドの取率，反応速度の点で，工業的に興 味をひくるのは少ない。

これらの報告によれば, 常厌でフェニルシクロへキサンを酸化 する場合, $105^{\circ} \mathrm{C}$ で 75 時間後に、フェニルシクロへキサン中の ヒドロペルオキシド濃度は $18 \%$ となる1。温度を上げて初期に $130^{\circ} \mathrm{C}$ ，つぎに $120^{\circ} \mathrm{C}$ とすれ隹合計 8 時間後にとドロペルオキシ ドは 20\% に達する2)。カキマゼ機を用い，気一液の接触をよくす ると酸化速度はさらに大きくなる

* 阑電化工業株式会社研究所：群馬県涉川市大崎.

1) E. B. Mc Call, D. S. P. Roebuck, B.P. 681,613 (1952).

2）秋吉，田代，金山，工化 60，269（1957）.

3) Stamicarbon N. V. 会社, B. P. 740,022 (1955).
ルムアルデヒドを加えるとよいことが述べられているず。酸化反 応によって副生する酸性物質の妨害作用を抑制するためにアルカ リ性物質を添加することが行なわれる。アルカシ性物質として,

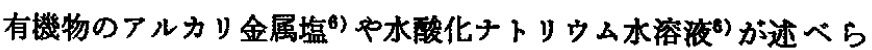
れている。

これらの報告の中で，ヒドロペルオキシドの収率について言及 したものは少ない。またまれに言及してあっても，その值はかな り低いか，あるいは高い場合でるヒドロペルオキシドの生成速度 は極めて小さいか。

著者らは，反応条件とヒドロペルオキシドの取率との関係を詳 細に検討した。ヒドロペルオキシドの生成速度が焏めて小さくな るよらなおだやかな反店条件を用いても，同時にヒドロペルオキ シドの熱分解反応が起こる。しかし分解反応が活発になればヒド ロペルオキシドの生成反応る活発になる。これは分解反応によっ て, ラジカルが新たに生成するからであろう。クメンヒドロペル オキシドはクメンの酸化によって容易によい取率でえられたが,

4) Montecatini 会社, B. P. 841, 157 (1960).

5) Rohne Poulenc 会社, 特昭 29-6031 (1954).

6) Rohne Poulenc 会社, B.P. 711, 392 (1954). 
これはこの化合物が生成し易く，しかもその反応条件で比較的安 定であることを示している。これ仅し 1-フェニルシクロへキ サンー1ーヒドロペルオキシドをよい収率で党ることが困難なのは， このものが生成し難く，しかも酸化条件で比較的不安定であるこ とを示するのである。しかしながらフェニルシクローキサン弱 アルカリ性物質を加光，温度の調節を政密に行ない，酸素を含む ガスと液相との接触面を增加させることによって，工学的にも興 味ある反応速度で，1-フェニルシクロヘキサン-1-ヒドロペルオ キシドをほとんど定量的な收率でえることができた。

\section{2 実験結果および考察}

\section{$2 \cdot 1$ オートクレーブによる実験}

原料のフェニルシクロヘキサンは塩化シクロヘキシルとベンゼ ンとのフリーデル・クラフッ反応により合成した7)。bp 232 234 ${ }^{\circ} \mathrm{C}, n_{\mathrm{D}}^{20} 1.528$ 。反応器は 18-8クロムーニッケル鋼製の電磁かき まぜ式オートクレーブ※1を使用した。これにフェニルシクロへキ サンと添加物を入れ，空間を適当に残す。空間们酸素を $20 \mathrm{~atm}$ 程度に医入してオートクレーブを電気炉で加熱し，一定の温度に 保つ。オートクレーブ内容物は翼の上下動（每分 40 60 回）に よってかきませられる。応が進んで酸素が吸収され，オートク レーブの内圧は減少する。酸素の吸収量は，オートクレーブの空 間部の容積と王力の诚少とから算定した。酸素の吸収量が所定の 值に達したならば，内圧を放気化よって除き，オートクレーブを 急冷する。反応液を取出して添加物の相とフェニルシクロへキサ ンの相とを分離した。フェニルシクロへキサンヒドロペルオキシ ドは, フェニルシクロへキサンの相に溶解しているが，その量は ヨウ素滴定法によって定量される。

酸素炕上る酸化実験の一例を表 1 飞示す。

フェニルシクロヘキサン基準のヒドロペルオキシドの収率が重 要な意味を持っているが，これをえることは比較的困難であるか ら，ここで酸素基準の収率で検討を行なった。酸素基準の収率 が高い場合には、フェニルシクロヘキサン基準の収率もほとんど 同じ值になっている。

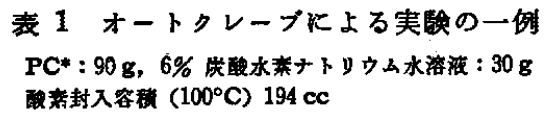

\begin{tabular}{|c|c|c|c|c|c|c|c|}
\hline $\begin{array}{l}\text { 畤 閏 } \\
(\mathrm{hr})\end{array}$ & $\begin{array}{l}\text { 温 度 } \\
\left.{ }^{\circ} \mathrm{C}\right)\end{array}$ & $\begin{array}{l}\text { 压为 } \\
\text { 音-音 } \\
(\mathbf{k g} / \\
\left.\mathbf{c m}^{2}\right)\end{array}$ & 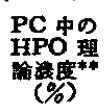 & $\begin{array}{c}\text { 㭙 間 } \\
(\mathrm{hr})\end{array}$ & $\begin{array}{c}\text { 温 度 } \\
\left({ }^{\circ} \mathbf{C}\right)\end{array}$ & 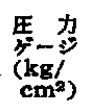 & 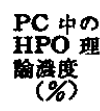 \\
\hline 0 & 100 & 20.0 & - & 12 & 101 & 18.6 & 1.9 \\
\hline 1 & 97 & 19.9 & 0 & 13 & 103 & 18.2 & 2.5 \\
\hline 2 & 98 & 19.9 & 0 & 14 & 99 & 17.8 & 2.9 \\
\hline 3 & 99 & 20.0 & 0 & 15 & 97 & 17.4 & 3.3 \\
\hline 4 & 100 & 20.0 & 0 & 16 & 100 & 17.0 & 4.0 \\
\hline 5 & 98 & 19.9 & 0 & 17 & 102 & 16.4 & 4.8 \\
\hline 6 & 102 & 19.9 & 0.25 & 18 & 101 & 16.0 & 5.3 \\
\hline 7 & 97 & 19.7 & 0.40 & 19 & 98 & 15.6 & 5.8 \\
\hline 8 & 101 & 19.6 & 0.55 & 20 & 102 & 15.0 & 6.7 \\
\hline 9 & 102 & 19.5 & 0.70 & 21 & 98 & 14.1 & 7.6 \\
\hline 10 & 100 & 19.3 & 1.1 & 22 & 101 & 13.2 & 8.8 \\
\hline 11 & 97 & 18.9 & 1.5 & 23 & 100 & 12.2 & 10.1 \\
\hline
\end{tabular}

* フェニルシクローキサンを PC と路す。

** 1ーフェニルシクロヘキサン-1-ヒドロベルオキシドを HPO と略す。 生成物 $122 \mathrm{~g}$ ，神相 $92 \mathrm{~g}$ (HPO 含有变 $9.45 \%$ )

水相 $30 \mathrm{~g}$ (HPO 合有率 $0.03 \%$ )

吸收酸量 : $194(\mathrm{cc}) \times 7.6(\mathrm{~atm}) \times 273 / 373=1080(\mathrm{cc})=0.0482(\mathrm{~mol})$ HPO 生成皇 : $92(\mathrm{~g}) \times 0.0945=8.80(\mathrm{~g})=0.0458(\mathrm{~mol})$

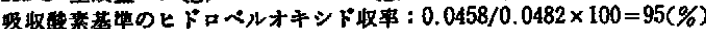

7) 中村, 盽岸, 表, 工化 65，206 (1962).

※1 坂下整作所製 SE-30 括上び SE-100。
反応生成液は，収率の离い場合には一般に着色がわずかであ り，取率が低い場合飞恃黄色あるいは褐色を呈している。水溶液 が共存する反応の場合には，まず水相の着色が激しくなり，それ につれて油相も着色してくる。反応液の着色の程度によって取率 の大体の目安がつく。

\section{$2 \cdot 2$ クメンとフェニルシクロヘキサンの酸化反応の比較}

クメンの酸化について一般に述べられている反応条件に従って クメンおよびフェニルシクロヘキサンをそれぞれ処理し，反応性 の比教を行なっだ。

2.2.1 クメンの酸化 クメンはイソプロパノールとベンゼン をフリーデル・クラフッ反応させて合成した。 bp 151 152 ${ }^{\circ} \mathrm{C}$, $n_{\mathrm{D}}^{20} 1.4925$, これを $5 \%$ 水酸化ナトリウム水溶液ととるにオート クレーブに入れ，酸菜を压入して酸化した。温度は $110 \sim 125^{\circ} \mathrm{C}$, 圧力壮 $30 \rightarrow 20 \mathrm{~kg} / \mathrm{cm}^{2}$ で行なった。反応系が酸素を吸収し始め

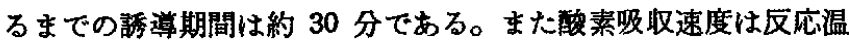
度によって左右される。一定温度においては時間と吸収量の関保 は活とんど直線的である。吸收酸素対クメンのモル比は 30 40\% としたが，酸秦基準のクメンヒドロペルオキシドの取率はすべて 100\%に近かった。

結果を表 2 亿示す。

表 $2 ク x ン の$ 酸 案酸 化

\begin{tabular}{|c|c|c|c|c|c|}
\hline \multicolumn{6}{|c|}{ クメン: $90 \mathrm{~g}, 5 \%$ 水酸化ナトリウム水溶没 $: 30 \mathrm{~g}$, 压力: $30 \rightarrow 20 \mathrm{~kg} / \mathrm{cm}^{2}$} \\
\hline $\begin{array}{c}\text { 反底溫度 } \\
\left({ }^{\circ} \mathrm{C}\right)\end{array}$ & $\begin{array}{l}\text { 反応時聞 } \\
\text { (min) }\end{array}$ & 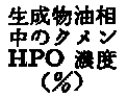 & $\begin{array}{c}\text { 酸秦/クメン } \\
\text { モル比 } \\
(\%)\end{array}$ & 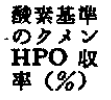 & 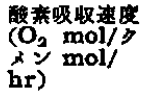 \\
\hline 110 & 410 & 41.2 & 35.8 & 99 & 0.052 \\
\hline 112.5 & 395 & 45.2 & 40.0 & 98 & 0.061 \\
\hline 115 & 260 & 42.1 & 36.9 & 98 & 0.086 \\
\hline 117.5 & 190 & 46.0 & 40.6 & 99 & 0.13 \\
\hline 120 & 110 & 36.8 & 32.3 & 97 & 0.18 \\
\hline 122.5 & 80 & 40.5 & 35.5 & 98 & 0.26 \\
\hline
\end{tabular}

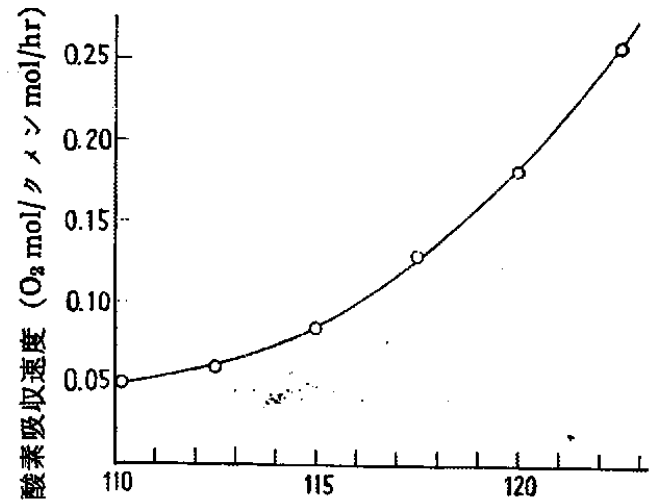

反分温度 $\left({ }^{\circ} \mathrm{C}\right)$

图 1 クメンの酸化における反応温度と酸素吸取速度の関係

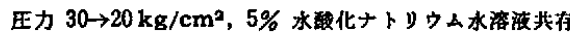

反応温度と酸素吸収速度との関係を図 1 亿示す。酸素吸収速度 の值は，かきま状況や，代力，添加物等炕ょって変わると思 われるが, 温度は最る重要な因子の一つであろう。

2.2.2 フェニルシクロヘキサンの酸化 クメンの酸化と同じ 条件によってフェニルシクロへキサンの酸化を行なった。諝導期 間は約 2 時間であった。クメンの 30 分に比較して長い。また酸 素吸取速度る小さく,クメンの 1/4 1/5 である。この速度は反 応温度が高い情ど大きいけれども，一方反応開始後の時間の経過 につれて大きくなる。つまり反応系のヒドロペルオキシドの濃度 が大になると速度る大になる。この点もクメンの場合と供なる。 
表 37 エルシクロヘキサンの酸素酸化

$P C: 90 \mathrm{~g}, 5 \%$ 水酸化ナトリウ৯水溶液 $: 30 \mathrm{~g}$, 压力: $30 \rightarrow 20 \mathrm{~kg} / \mathrm{cm}^{2}$

\begin{tabular}{|c|c|c|c|c|c|}
\hline $\begin{array}{c}\text { 反底鼬度 } \\
\left({ }^{\circ} \mathrm{C}\right)\end{array}$ & $\begin{array}{c}\text { 反応胿間 } \\
\text { (min) }\end{array}$ & $\begin{array}{l}\text { 生成物丽相 } \\
\text { 中心 } \\
\text { 浩度 }(\%)\end{array}$ & $\begin{array}{c}\text { 酸势/PC } \\
\text { ₹ル比 } \\
(\%)\end{array}$ & 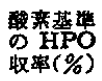 & 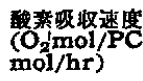 \\
\hline 110 & 1800 & 27.3 & 38.8 & 61 & 0.013 \\
\hline 115 & 570 & 21.4 & 30.0 & 61 & 0.032 \\
\hline 120 & 195 & 18.2 & 27.6 & 56 & 0.085 \\
\hline
\end{tabular}

ヒドロペルオキシドの取率る低い。

結果を表 3 に示した。

\section{3ヒドロベルオキシドの収率に及ぼす反応条件}

2.3.1 アルカリ添加剤と收率 アルカリ添加剂として, 水酸

表 4 フルカリ添加都の影䇾 PC : $300 \mathrm{~g}$ (HPO 含有平 $0.5 \%$ ), 印力 $20 \rightarrow 9$ $\mathrm{kg} / \mathrm{cm}^{2}$, 澡度 $: 120 \rightarrow 100^{\circ} \mathrm{C}$, 酸秦吸收速度 : $0.011 \mathrm{~mol} / \mathrm{PC} \mathrm{mol} / \mathrm{hr}$ 一定

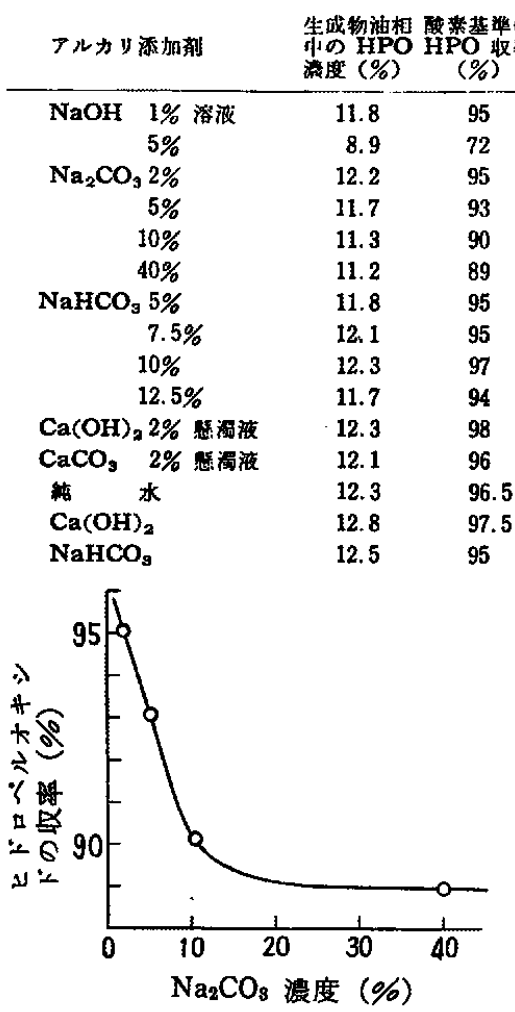

図 2 フルカリ添加剂としての炭酸ナト リウム水溶液の濃度と収率の関係

正力 : $20 \rightarrow 9 \mathrm{~kg} / \mathrm{cm}^{2}$, 埧度 : $120 \rightarrow 100^{\circ} \mathrm{C}$

てもよい結果を与える。

（d）水酸化カルシウムは水とともに添加しても，無水で添加 してもよい結果を与えている。また炭酸カルシウムるよい結果を 与えた。

（e）水だけを加えた場合，収桼は良好であるが反応液の着色 が湤しい。またこの場合は反底系内の微量の不純物の影響をうけ やすい。

（f）無水の場合と，水溶液，水懸濁液を用いる場合とを比較 してみる。水を添加すると水の熱容量が反応系の安定性を增加す る役割を果し，さらに反応で生じた不純物の抽出剤としても役立 っている。我を用いないと酸素吸収速度は幾分大きい。しかし反 応液の着色は水を用いる場合にくらべて激しい。水酸化カルシウ ムの場合にのみ，無水でも全く然色のものがえられた。

$2 \cdot 3 \cdot 2$ 吸收酸素対フェニルシクロヘキサンのモル比と収象 反応系に吸収された酸素対フェニルシクロヘキサンのモル比が，
ヒドロペルオキシドの取 率とどのような関係をる っているかを検討した。 フェニルシクロヘキサン が酸素を吸収し，ヒドロ ペルオキシドの濃度が高 くなるにつれて生成反応 歹分解反応主活発火な る。すなわら酸素吸取速 度は増大するが取率は低 下して行く。このような 関係を見出したので，以 下の実験では酸素吸取速 度を一定に保つために反

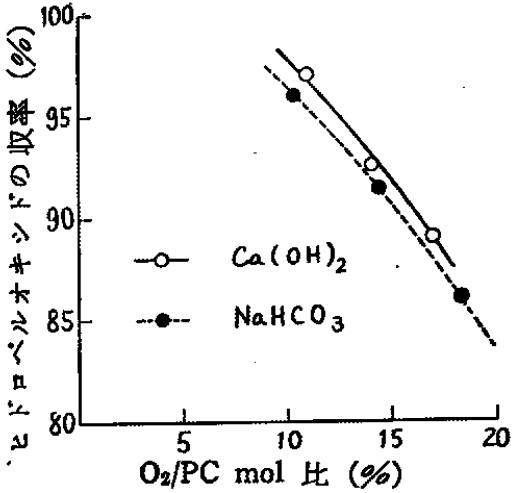

図 3 吸収酸素対フェニルシクロヘキ サンの $\mathrm{mol}$ 比之取率の成保 压力: $20 \rightarrow 10 \mathrm{~kg} / \mathrm{cm}^{2}$, 蛋度 : $120 \rightarrow 100^{\circ} \mathrm{C}$, 酸显吸收速度 : $0.011 \mathrm{~mol} / \mathrm{PC} \mathrm{mol} / \mathrm{hr}$
応の進行とともに，反応温度を下げて分解反応の速度が增大する のを抑えた。

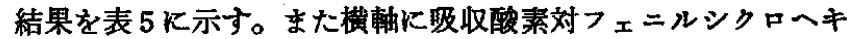
サンのモル比，綎糨にヒドロペルオキシドの取率をとり，目3に プロットする。

表 5 吸収酸素対 $ェ$ ニルシクロヘキサンのモル比と收率の䦛係 $P C: 300 \mathrm{~g}$ (HPO 含有事 $0.5 \%$ ), 压力: $20 \rightarrow 10 \mathrm{~kg} / \mathrm{cm}^{2}$,

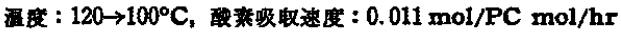

\begin{tabular}{|c|c|c|c|c|}
\hline & $\begin{array}{c}\text { 素/PC } \\
(\%)\end{array}$ & $\begin{array}{l}\text { 生成物油相中 } \\
\text { WPO理 } \\
\text { 度 }(\%)\end{array}$ & 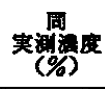 & 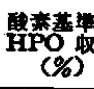 \\
\hline \multirow[t]{4}{*}{ (1) } & $\mathrm{Ca}(\mathrm{OH}$ & $g$ 㴽加 & & \\
\hline & 11.0 & 13.8 & 13.4 & 97.0 \\
\hline & 13.9 & 17.1 & 15.9 & 92.5 \\
\hline & 17.7 & 21.3 & 19.1 & 89 \\
\hline \multirow{4}{*}{ (2) } & Naficc & \% 水溶浙 $100 \mathrm{~g}$ & & \\
\hline & 10.4 & 13.1 & 12.6 & 96 \\
\hline & 14.5 & 17.7 & 16.3 & 91.5 \\
\hline & 18.3 & 22.0 & 19.1 & 86 \\
\hline
\end{tabular}

以上の結果から、ヒドロペルオキシドの取率は上述のような考 虑をしても吸収酸菜対フェニルシクロへキサンのモル比を大きく するはど低下することがあきらかとなった。このことは，反终年 件ではヒドロペルオキシドが不安定で，分解を起すことを示す。

2.3.3 酸絫吸収速度と収隶同一のかきまぜの状況下で, 温 度を上年させて酸素吸収速度が大きくなる場合のヒドロベルオキ シドの取率について検討した。この場合には温度によるヒドロペ ルオキシド生成反応と分解反応の競争がどのようなるのであるか といら検討になる。

吸取酸素対フェニルシクロ ヘキサンのモル比が約 $11 \%$ になるまで反応させた。そし て反応温度を調節することに より，希望する一定の酸素吸 収速度を保った。

結果を表 6 に示す。横軸に 酸素吸収速度，絽軸に取率を とって图 4 Kプロットする。

これらの実験からつぎの結 論がえられる。

(a) オートクレーブ実釨 では, 酸素吸收速度が 0.01 $0.02 \mathrm{~mol} / \mathrm{PC} \mathrm{mol} / \mathrm{hr}$ では, 収

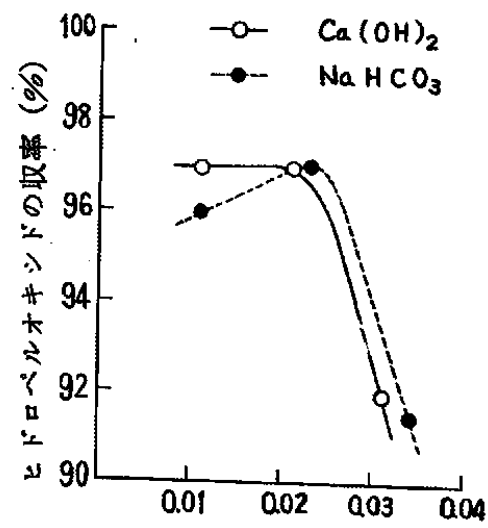

酸素吸収速度 $\left(\mathrm{O}_{2} \mathrm{~mol} / \mathrm{PC} \mathrm{mol} / \mathrm{hr}\right)$ 図 4 酸素吸収速度之収密の周 出 : $20 \rightarrow 10 \mathrm{~kg} / \mathrm{cm}^{2}$ 
表 6 酸素吸収速度と収率の関係

$\mathrm{PC}: 300 \mathrm{~g}$ (HPO 含有事 $1 \%$ ), 印力 $20 \rightarrow 10 \mathrm{~kg} / \mathrm{cm}^{2}$

\begin{tabular}{|c|c|c|c|c|}
\hline 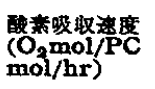 & $\begin{array}{c}\text { 反惢温度 } \\
\text { 籍 } \\
\left({ }^{\circ} \mathrm{C}\right)\end{array}$ & $\begin{array}{l}\text { 生成物油相中 } \\
\text { 草PO理猃 } \\
\text { (\%) }\end{array}$ & 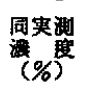 & 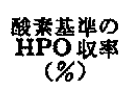 \\
\hline \multicolumn{5}{|c|}{ (1) $\mathrm{Ca}(\mathrm{OH})_{2} 5 \mathrm{~g}$ 添加 } \\
\hline 0.011 & $120 \sim 100$ & 13.8 & 13.4 & 97 \\
\hline 0.021 & $125 \sim 102$ & 13.2 & 12.8 & 97 \\
\hline 0.031 & $130 \sim 105$ & 13.6 & 12.6 & 92 \\
\hline \multicolumn{5}{|c|}{ （2） $\mathrm{NaHCO}_{3} 5 \%$ 水溶液 $100 \mathrm{~g}$ 媇加 } \\
\hline 0.011 & $120 \sim 100$ & 13.1 & 12.6 & 96 \\
\hline 0.023 & $125 \sim 102$ & 13.9 & 13.5 & 97 \\
\hline 0.034 & $130 \sim 105$ & 13.7 & 12.6 & 91.5 \\
\hline
\end{tabular}

表 7 反応の進行度と反応温度

\begin{tabular}{|c|c|c|c|c|c|c|}
\hline \multirow{2}{*}{ 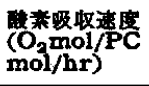 } & \multicolumn{6}{|c|}{ 反応造行度（HPO 源度 \%) } \\
\hline & $(\%)$ & 2 & 5 & 8 & 10 & 13 \\
\hline 0.011 & $120\left({ }^{\circ} \mathrm{C}\right)$ & 115 & 110 & 107 & 104 & 100 \\
\hline 0.022 & 125 & 119 & 114 & 110 & 107 & 102 \\
\hline 0.033 & 130 & 123 & 118 & 114 & 110 & 105 \\
\hline
\end{tabular}

率は 96 97\% で良好であるが，この值が 0.03 になると急激に 低下する。

（b）この原因は温度にある。反応温度が反応の進行につれて どのように変わっているかを表 7 にまとめてみた。

（c）酸素吸取速度を大きくするために温度を上界させること は不得策である。ヒドロペルオキシドを生成する主反応の反応速 度よりも，分解反応の反応速度の方がいっそ5大きい温度勾配を 有していることがあきらかである。

\section{4 常圧酸化法による添加绪の検討}

フェニルシクロヘキサンは常压であ酸化されてヒドロペルオキ シドを生成する。この場合，ヒドロペルオキシドの生成速度は小 さいが, 反応の途中で試料を取出して分析することる容易であ り，添加剂の影響を検討するのに便利てある。

実邪方法：フェニルシクロヘキサンと $5 \%$ 炭酸水素ナトリウム 水溶液を反応器に入れ, 温度を $95^{\circ} \mathrm{C}$ 保って空気を吹込む。

2.4.1 反応開始郕としてのヒトロペルオキシト ヒドロペル オキシドをあらがめ $0.96 \%$ 含むフェニルシクロヘキサンを用 ふて実験を行なうと，15 時間後に 2.82\%に達する。ヒドロペル オキシドを最初に加光ない場合は，18時間後でる0.04\%になる

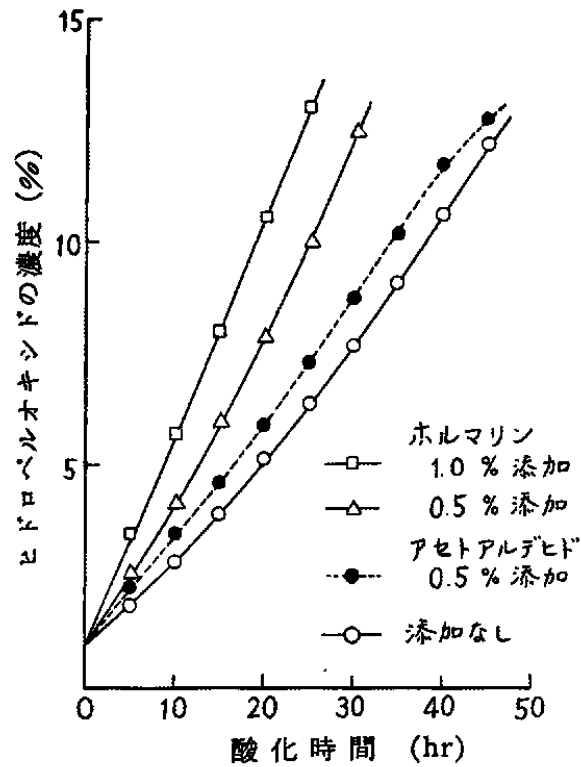

园 5 フルデヒド添加の影㻥

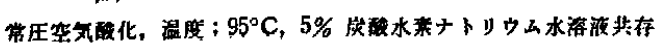

にすぎない。ヒドロペルオキシドの存在が反応の進行に極めて重 要であることがあきらかである。

2.4.2 反応促進剂としてのアルデヒド ホルマリン (40\%) あるいはアセトアルデヒド (80\%) を加光，その影隌をしらべた。 ヒドロペルオキシドの生成状況を図 5 に示す。ヒドロペルオキシ ドはあらかじめ 1\%加えて拈いた。

ホルマリンあるいはアセトアルデヒドの添加によって反応速度 は大きくなっている。ホルムアルデヒドはヒドロペルオキシドと 同じような作用を有しているものと考えられる。しかもいっそう 低い温度で有效である。しかしこの場合, 反応液は黄色になる。 また反灿の途中で，さらにホルマリンを追加した埸合にはヒドロ ペルオキシドの濃度が低下し，反応液の着色はひどくなった。ア セトアルデヒドも同じよ5に反応促進剂として役立つがその効果 は幾分劣る。

2.4.3 アルカリ添加都 アルカリ添加剤の影響について，加 圧酸化の結果はすでに述べたが，常圧の場合もまったく同様の結 果がえられた。ヒドロペルオキシドの生成状況を図6に示す。

$2 \cdot 5$ 塔式反度器による加圧酸化

図 7 に示すような装置を用いた。酸化塔は18-8クロムーニッケ

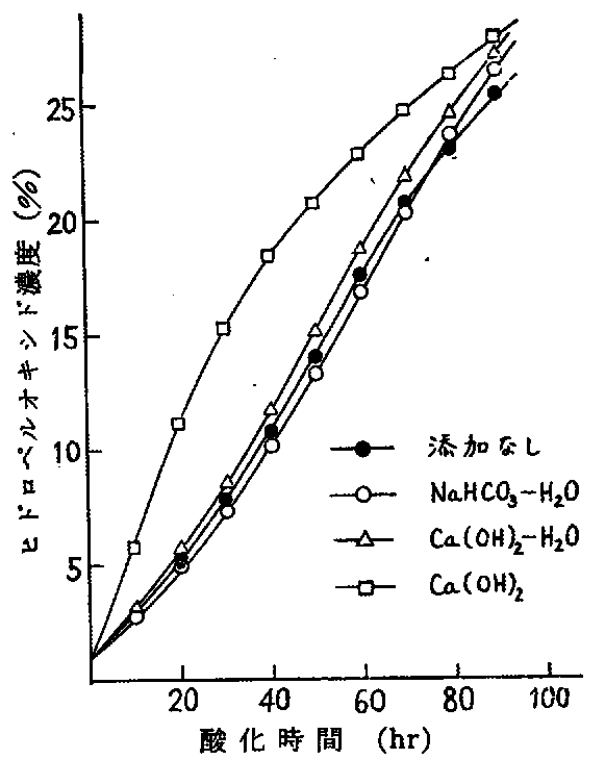

园6 6 ルカリ添加剂の影㹕 常王空気酸化, 溫度 : $95^{\circ} \mathrm{C}$

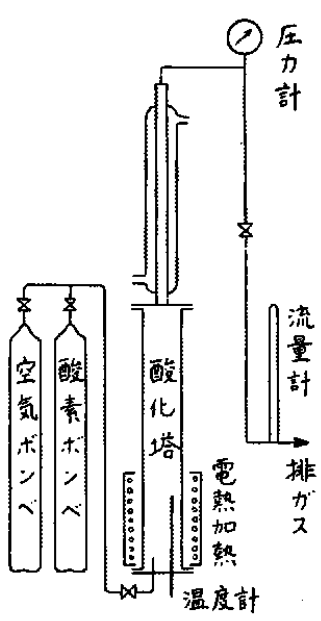

図 7 塔式酸化装置

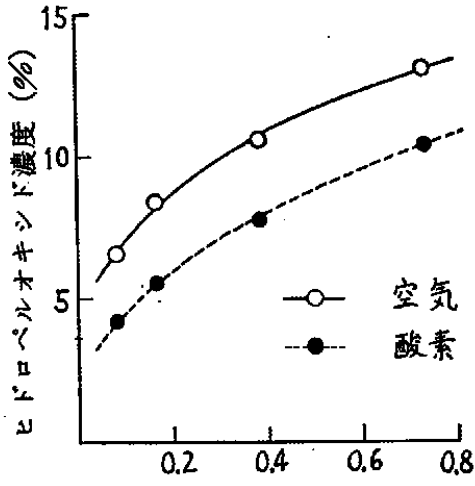

ガス供給速度 $\left(\mathrm{O}_{2} \mathrm{~mol} / \mathrm{PC} \mathrm{mol} / \mathrm{hr}\right)$

図 8 塔式酸化䒾置におけるガス供給 速度ととドロヘルオキシドの生成量 酸絭の場合怡吹迈速度 $=$ 供唋速度 代力: $10 \mathrm{~kg} / \mathrm{cm}^{2}$, 温度: $120 \sim 100^{\circ} \mathrm{C}, 4 \mathrm{hr}$ 
ル鋼製で内径 $6 \mathrm{~cm}$. 高さ $1 \mathrm{~m}$ である。塔底にはガラス半融多孔 分散板を持つガス吹込み口がある。塔頂には凝縮器，仕力計，排 気弁扰よびガス流量計がとりつけてある。

ヒドロペルオキシドを $1 \%$ 含有するフェニルシクァヘキサン $600 \mathrm{~g}$ と，5\% 炭酸水素ナトリウム水溶液 $200 \mathrm{~g}$ を酸化塔火仕込 み、酸案または空気を压入した。塔内を $10 \mathrm{~kg} / \mathrm{cm}^{2}$ に保ち, 排 気弁を開いて一定速度で排受した。

結果を表 8 K示す。ガス吹込み速度と，反応開始後 4 時間後の 反応液のヒドロペルオキシド濃度との関係を図 8 K示した。

表 8 塔式反応器による加仕酸化

\begin{tabular}{|c|c|c|c|c|c|c|}
\hline \multirow{2}{*}{ 吹込みガス } & \multicolumn{4}{|c|}{ 反応㭙間 $(\mathrm{hr}$ ) } & \multirow{2}{*}{$\begin{array}{l}\text { 排舜貫 } \\
(\text { (l/min) } \\
\text { (NTP) }\end{array}$} & \multirow{2}{*}{$\begin{array}{l}\text { 生成物油相 } \\
\text { 中田 } \\
\text { (\%) }\end{array}$} \\
\hline & $120^{\circ} \mathrm{C}$ & $110^{\circ} \mathrm{C}$ & $100^{\circ} \mathrm{C}$ & 合 竐 & & \\
\hline 醊 东 & 0.5 & 1.0 & 2.5 & 4.0 & 0.1 & 4.2 \\
\hline " & 0.5 & 1.0 & 2.5 & 4.0 & 0.2 & 5.7 \\
\hline$"$ & 0.5 & 1.0 & 2.5 & 4.0 & 0.5 & 7.9 \\
\hline$"$ & 0.5 & 1.0 & 2.5 & 4.0 & 1.0 & 10.3 \\
\hline 空 匃 & 0.5 & 1.0 & 2.5 & 4.0 & 0.5 & 6.7 \\
\hline$"$ & 0.5 & 1.0 & 2.5 & 4.0 & 1.0 & 8.3 \\
\hline$"$ & 0.5 & 1.0 & 2.5 & 4.0 & 2.5 & 10.5 \\
\hline " & 0.5 & 1.0 & 2.5 & 4.0 & 5.0 & 13.1 \\
\hline$" 1$ & 0.5 & 1.0 & 1.5 & 3.0 & 5.0 & 9.8 \\
\hline " & 0.5 & 1.0 & 2.0 & 3.5 & 5.0 & 11.6 \\
\hline " & 0.5 & 0.5 & 2.5 & 3.5 & 5.0 & 10.7 \\
\hline
\end{tabular}

以上の結果がらつぎの結論がえられる。

（a）オートクレーブの実鈳に比較して，反応の速度が増加し た。また吹込みガス量を多くする方がよい結果を与えていること からみても，気一液の接触面䅡を大きくすることは重要な因子で ある。

（b）空気を用いると酸紮の分圧は下がるわけであるが，供給 酸素量を同じにした場合，接螌面の增大の影蠁の方が大きく，む しろよい結果がえられる。

（c）これらの実験では吹込まれた酸素の一部が反応し，大半 は排気されている。しかし，フェニルシクロへキサン液相の厚さ

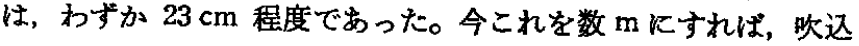
み酸素の大半が反応することになる。

（d） 反応時間は3 時間程度で，ヒドロペルオキシドの濃度が 10\% の反応生成液が兄られる。

（e）以上の実験に打ける反応生成液は全く無色であった。 ドロペルオキシドの取率は求められないが，反応液の着色の程度 から判断して 95\% 以上であると考えられる。

\section{3 総括}

（1）フェニルシクロヘキサンを酸化すると，1-フェニルシク
ロヘキサン-1-ヒドロペルオキシドが生成する。この反応はクメ ンの場合に比較すると反応速度が小さい。をたヒドロペルオキシ ドの安定性も小さい。

（2）反応の開始および促進には，ヒドロペルオキシド自身が 役立つ。

（3）反応で副生する酸性物質による夆は，反応系にアルカリ を添加することによって防ぐことがでる。アルカリ泒加剤とし ては，水酸化カルシウム，炭酸氷素ナトリウム等の弱アルカリ性 物質がすぐれている。

（4）温度の上丹年よび反㐫系のヒドロペルオキシドの濃度の 上年につれて，生成反底と分解反応の双方が促進される。分解反 応が起らぬようにするには，まず温度を反応液中のヒドロペルオ キシドの濃度に応して制御しなければならない。そして反応液中 のヒドロペルオキシドの濃度が 10〜20\%に達すれば，反応をと めなければならない。ヒドロペルオキシドの濃度と，それに応し て制御すべき温度の一例は表 7 に示した。

（5）フェニルシクロヘキサンと, 酸素を含むガスとの按触面 を增大させることは，ヒドロペルオキシドの生成反応だけを促進 する方法として極めて効果的である。

（6）王力が大きい注ど，反応速度は大である。王力を大きく したために収率が低下することはない。

（7）アルデヒド類は反応促進倣として役立つ。特にホルムア ルデヒドは効果的である。これらは一般にいわれているように反 応系でまず酸化を受けてペルオキシド（過酸）となり，このすの がラジカル源となるのであろう。

（8）ヒドロペルオキシドの分解が起るときに，酸素吸取速度 る大きくなるのは分解反応你してラジカルが発生していること を示すのであろう。熱分解隹よって，1-フェニルシクロヘキシル アルコールが生成しているので，その分解機構は一般にいわれて いるよ5に次式によるのかる知れない。

$$
\begin{aligned}
& \mathrm{ROOH} \longrightarrow \mathrm{RO} \cdot+\cdot \mathrm{OH} \\
& \mathrm{RO}+\mathrm{RH} \longrightarrow \mathrm{ROH}+\mathrm{R} \cdot \\
& . \mathrm{OH}+\mathrm{RH} \longrightarrow \mathrm{H}_{2} \mathrm{O}+\mathrm{R} .
\end{aligned}
$$

（たたしRは 1-フェニルシクロヘキシル基） しかし反応系に，過酸化水素 (30\%) を加えながら酸化させてる， 反応は全く促進されないことから，（3）式に確証はない。

（昭和 36 年 4 月，日化第 14 年会講演）

御指導をいただいた東京工業大学 岩倉義男教授，ならびに当 社專務取締役 高瀬理三郎氏に感謝いたします。また実験に協力 された 当所下城茂夫氏に感謝いたします。 